\title{
Reaction of melon genotypes to Didymella bryoniae (Fuckel) Rehm
}

Lucas da S. Santos ${ }^{1 *}$, Willame dos S. Cândido ${ }^{1}$, Hudson de O. Rabelo ${ }^{1}$, Marcus V. Marin ${ }^{1}$, Lucas A. Gaion ${ }^{1}$, Rafaelle F. Gomes ${ }^{2}$, Margarete Camargo ${ }^{1}$, and Leila T. Braz ${ }^{1}$

\section{ABSTRACT}

The cultivation of melon (Cucumis melo L.) in greenhouses has contributed to the increased incidence of fungal diseases, particularly gummy stem blight caused by Didymella bryoniae (Fuckel) Rehm. This disease is currently considered the main disease affecting this crop, causing conditions such as water soaked seedlings, and stem and fruit cankers, reducing productivity and fruit quality. Considering the importance of this disease, the aim of this study was to evaluate the reaction of different $C$. melo genotypes to D. bryoniae. Sixty-eight different melon genotypes were investigated. Two phenotyping assays were performed to investigate the resistance to the disease, following a randomized block design with four replicates. Subsequently, a new assay was conducted to validate the resistance of the genotypes selected in the previous step, using a randomized block design with three replicates. The plants were inoculated using the toothpick method, and resistance was evaluated according to a grading scale. Also, reaction classes and assay groups were used for classifying the resistance level of the genotype. The JAB-11 and JAB-20 strains were susceptible to the pathogen, as well as the commercial hybrids Louis $\mathrm{F}_{1}$ and Fantasy $\mathrm{F}_{1}$. The hits AC-29, C160, Charentais Fom 1, PI 420145, PI 482398 and PI 532830 were resistant to $D$. bryoniae, and could become an important gene source for the development of resistant cultivars.

Key words: Acessions, Cucumis melo, phenotyping, gummy stem blight.

${ }^{1}$ Universidade Estadual Paulista (UNESP), Faculdade de Ciências Agrárias e Veterinárias (FCAV), via de Acesso Prof. Paulo Donato Castellane s/n, 14884-900, Jaboticabal, São Paulo, Brasil.

"Corresponding author (lucasmelhorista@gmail.com).

${ }^{2}$ Universidade Federal Rural da Amazônia (UFRA), Departamento de Agronomia, Capanema, Pará, Brasil.

Received: 28 June 2016

Accepted: 11 November 2016

doi:10.4067/S0718-58392017000100009

\section{INTRODUCTION}

The melon (Cucumis melo L. subsp. melo var. cantalupo Ser.) culture is gaining prominence in relation to vegetable crops produced in Brazil, especially due to exports. The Brazilian melons are exported mainly to The Netherlands, Spain, UK and Italy (Agrianual, 2016). The country exports increased from $3 \%$ to $34 \%$ of total production from 2013 to 2014, respectively (Agrianual, 2016).

The state of São Paulo is the largest consumer market of melon in Brazil, of the total sold in the country in 2014; over $22 \%$ were sold at Companhia de Entrepostos e Armazéns Gerais de São Paulo (CEAGESP; Agrianual, 2016). However, the production of this vegetable crop in the state is small compared to demand, thus requiring greater investment in the culture.

Producers in São Paulo prefer to grow melon in greenhouses, especially cultures of noble melons, as the muskmelon. The state has a promising market for this type of melon, with a production capacity that is lower than the market demand.

The expansion of the melon cultivation in the Southeast has contributed to the increased incidence of fungal diseases such as powdery mildew, Podosphaera xanthii (Castagne) U. Braun \& Shishkoff and especially gummy stem blight, caused by Didymella bryoniae (Fuckel) Rehm. The latter is the causal agent of the main fungal diseases in melon (Ito et al., 2009; Silva et al., 2012) and watermelon (Santos et al., 2013) crops cultured in both open and protected environments.

The ascomycete $D$. bryoniae is one of the most relevant pathogens in the world, causing significant economic losses to the Cucurbitaceae family, particularly melon, watermelon and cucumber (Babu et al., 2015; Keinath, 2015). Gasparotto et al. (2011) reported that gummy stem blight is the most devastating disease in melon (Cucumis melo var. reticulatus and Cucumis melo L. subsp. melo var. cantalupo Ser.) grown in greenhouses in Paraná, and may cause up to $100 \%$ damage to the crops. In São Paulo, it is not different, as the disease has also caused substantial losses.

The control of this pathogen is difficult since the use of chemicals is not very effective, and can cause negative impacts to the environment and exert selection pressure, which may contribute to pathogen resistance to fungicides. There are reports of appearance of pathogen resistance to systemic fungicides based on benzimidazole and thiofanate, pyrimidine-carboxamide, methoxy-carbamates, which are used to control D. bryoniae in various cucurbits, especially in melons and watermelons (Keinath, 2015). 
The use of resistant rootstocks is another alternative; however, the costs and lack of seedling producers adopting the technique hamper its use. Moreover, there is the possibility of introgression of resistance genes by breeding melon lines; use of resistant cultivars is the most effective, environmentally sustainable, and cheapest method.

Although there are no cultivars resistant to $D$. bryoniae in the market, resistance sources with potential for use in breeding programs have been observed. As an example, accessions PI 140471, PI 157082, PI 511890 and PI 482398 have shown resistance conditioned by a dominant gene, whereas in the access PI 482399, the resistance is monogenic recessive, and five independent genes have been reported, named as $G s b-1, G s b-2, G s b-3, G s b-4$, and $g s b-5$, respectively.

Wolukau et al. (2007) reported that resistance to gummy stem blight in the access PI 420145 is also conferred by a single dominant gene, which is named Gsb-6 (Bi et al., 2015), its resistance level is equal to or even higher than the five accesses mentioned above.

Thus, it is essential to evaluate the behavior of Plant Introduction (PI's) with isolates of D. bryoniae from São Paulo, but also to evaluate the reaction of genotypes from the main Germplasm/genebanks collections of public institutions so that they can be used in melon breeding programs.

The objective of this study was to evaluate the reaction of $C$. melo genotypes to $D$. bryoniae, the pathogenic species that causes gummy stem blight.

\section{MATERIAL AND METHODS}

\section{Reaction of melon genotypes to $D$. bryoniae - Assays 1 and 2}

Of the three assays performed, two evaluated the reaction of genotypes while the third validated resistance to $D$. bryoniae. They were conducted in the Sector of Vegetable Crops and Aromatic Medicinal Plants and Plant Pathology Laboratory, Department of Plant Protection, Universidade Estadual Paulista (UNESP), Agricultural and Veterinary Sciences Faculty (FCAV), Jaboticabal (21 ${ }^{\circ} 15^{\prime} 22^{\prime \prime} \mathrm{S}$, 48 18'58” W; 595 m a.s.1.), São Paulo, Brazil.

Sixty-six genotypes were investigated regarding resistance to $D$. bryoniae, of which 29 genotypes were from EMBRAPA Hortaliças, 19 genotypes from the genebanks of EMBRAPA Tropical Climate. Another 12 genotypes originated from the genebanks of the Federal Rural University of Semi-Arid Region (UFERSA). In addition to the accesses PI 140471, PI 157082, PI 482398 and PI 420145, obtained from the North Central Regional Plant Introduction Station (USDA), containing D. bryoniae resistance genes (Table 1). Also, the JAB-11 and JAB-20 lines (Table 1) were used. These lines were developed by the melon breeding program of the UNESP-FCAV, and have good general combining ability (GCA), especially for the fruit mass $\left(\mathrm{kg}_{\text {fruit }}{ }^{-1}\right)$ and production $\left(\mathrm{kg} \mathrm{m}^{-2}\right)$ traits, which when combined resulted in a high-yielding $\mathrm{F}_{1}$ hybrid (Vargas et al., 2010).

Table 1. Taxonomic origin and classification of melon genotypes (Cucumis melo), evaluated for resistance to Didymella bryoniae. Jaboticabal, São Paulo, 2016.

\begin{tabular}{|c|c|c|c|c|c|c|c|c|}
\hline \multirow[b]{2}{*}{ Genotypes } & \multicolumn{2}{|c|}{ Embrapa Hortalíças } & \multirow[b]{2}{*}{ Genotypes } & \multicolumn{2}{|c|}{ Embrapa Clima Tropical } & \multirow[b]{2}{*}{ Genotypes } & \multicolumn{2}{|l|}{ UFERSA } \\
\hline & Botanic group & Origin & & Botanic group & Origin & & Botanic group & Origin \\
\hline Anô\#2 & - & Japan & C67 & Undet. landrace & Brazil & AC-01 & C. melo var. momordica & Brazil \\
\hline Catucho & - & Brazil & C68 & Undet. landrace & Brazil & AC-07 & Undet landrace & Brazil \\
\hline Charentais Fom 1 & - & France & $\mathrm{C} 70$ & Undet. landrace & Brazil & AC-11 & C.melo var. conomon & Brazil \\
\hline Cinco & - & USA & C71 & Undet. landrace & Brazil & AC-12 & C. melo var. conomon & Brazil \\
\hline Flexuosos 'M-2791' & C. melo var.flexuosus & Israel & $\mathrm{C} 72$ & Undet. landrace & Brazil & AC-17 & Undet. landrace & Brazil \\
\hline Irene & - & Brazil & C88 & Undet. landrace & Brazil & AC-23 & C. melo var. momordica & Brazil \\
\hline Kallósemjém & - & Hungary & $\mathrm{C} 160$ & Undet. landrace & Brazil & AC-24 & Undet. landrace & Brazil \\
\hline Melão Eldorado 300 & - & Brazil & $\mathrm{C} 163$ & Undet. landrace & Brazil & AC-25 & Undet. landrace & Brazil \\
\hline Melão Gaúcho & - & Brazil & C189 & Undet. landrace & Brazil & AC-28 & C. melo var. momordica & Brazil \\
\hline Melão Verdadeiro & - & Brazil & C190 & Undet. landrace & Brazil & AC-29 & C. melo var. momordica & Brazil \\
\hline Mi-Tang-Ting & - & Japan & C194 & Undet. landrace & Brazil & AC-30 & Undet. landrace & Brazil \\
\hline Perlita & - & UO & $\mathrm{C} 246$ & Undet. landrace & Brazil & $\mathrm{AC}-32$ & Undet. landrace & Brazil \\
\hline PI 124111 & C.melo subsp. melo & India & $\mathrm{C} 265$ & Undet. landrace & Brazil & & & \\
\hline PI 124112 & C.melo subsp. melo & India & $\mathrm{C} 272$ & Undet. landrace & Brazil & & & \\
\hline PI 140472 & C. melo subsp. melo & USA & C327 & Undet. landrace & Brazil & & & \\
\hline PI 164320 & - & USA & C329 & Undet. landrace & Brazil & & & \\
\hline PI 313970 & C. melo subsp. melo & India & C359 & Undet. landrace & Brazil & & & \\
\hline PI 414723 & C. melo subsp. melo & India & C384 & Undet. landrace & Brazil & & & \\
\hline PI 420149 & C. melo var. conomon & USA & & & & & & \\
\hline PI 420150 & C. melo var. conomon & China & & & & & & \\
\hline PI 532283 & C. melo var. conomon & China & & & & & & \\
\hline PI 140471 & C. melo subsp. melo & USA & & & & & & \\
\hline PI 157082 & C. melo subsp. melo & China & & & & & & \\
\hline PI 420145 & C. melo subsp. melo & Japan & & & & & & \\
\hline PI 482398 & C.melo subsp. melo & Zimbabwe & & & & & & \\
\hline PMR-45 & - & USA & & & & & & \\
\hline Solarking & Gália type & UO & & & & & & \\
\hline TM-001 & - & Japan & & & & & & \\
\hline
\end{tabular}

UFERSA: Federal Rural University of Semi-Arid Region, UO: unidentified origin. 
The reaction of genotypes to $D$. bryoniae was evaluated by two assays to optimize the available space, especially in the humidity chamber, in view of the large number of genotypes used. Assay 1 assayed 40 genotypes while assay 2 tested 33, and JAB-11, JAB-20, Flexuosos 'M-2791', PI 140471, PI 157082, PI 482398 and PI 420145. Seeds were sown in polystyrene trays containing 128 cells, using the commercial substrate (Bioplant, Bioplant Agricola Ltda., Nova Ponte, Minas Gerais, Brazil). Subsequently, they were placed in a greenhouse, seedlings were transplanted to pots after appearance of two fully developed leaves.

The assays were performed in a greenhouse from August 2013 to January 2014. The experimental design was a randomized block design with four replicates, each plot represented by two pots with four plants. In one pot, the plants were inoculated with the $D$. bryoniae isolate. In the control pot only small culture medium potato dextrose agar (PDA) disks were placed on the plants.

The $5 \mathrm{~L}$ ceramic pots used were arranged in rows spaced $1.0 \mathrm{~m}$ from one another and $0.5 \mathrm{~m}$ between pots, filled with a mixture of loam, sand and tanned manure, at 3:1:1 proportion. The mixture was sieved and autoclaved in advance at $120{ }^{\circ} \mathrm{C}$ and $101.3 \mathrm{kPa}$, for $45 \mathrm{~min}$.

The pathogen in its asexual stage (Phoma cucurbitacearum) was isolated from melon plants grown in a greenhouse in the Vegetable Crops and Aromatic Medicinal Plants Sector, UNESP-FCAV, Jaboticabal. The isolation of the pathogen was carried directly by removing the pycnidia formed in lesions of plants with typical symptoms of gummy stem blight. After obtaining the pure fungal culture, sub-culturing was performed in Petri dishes containing PDA culture medium, and 20 d later, medium fragments with $5 \mathrm{~mm}$ diameter containing fungus mycelium, were removed and used for inoculation.

The plants were inoculated $2 \mathrm{~d}$ after transplanting seedlings to the pots, using the toothpick method. This method consists of directly inserting the previously sterilized toothpicks, with the medium disk containing fungus cultures, in the stem near the cotyledons (Verzignassi et al., 2004). After inoculation, seedlings were kept in a humidity chamber for $72 \mathrm{~h}$ and then were placed in the greenhouse.

Figure 1 shows the mean temperature and relative humidity in the chamber during assays 1 and 2 . The plants were fertigated with a nutrient solution recommended for the crop, via drip, eight times a day for 5 min each time. The solution contained $805 \mathrm{~g}$ calcium nitrate, $277 \mathrm{~g}$ potassium nitrate, $238 \mathrm{~g}$ potassium chloride, $155 \mathrm{~g}$ monoammonium phosphate (MAP), $240 \mathrm{~g}$ magnesium sulfate, $36.6 \mathrm{~g}$ TensoIron $(\mathrm{Fe}), 2.54 \mathrm{~g}$ manganese sulfate, $1.90 \mathrm{~g}$ borax, 1.15 $\mathrm{g}$ zinc sulfate, $0.12 \mathrm{~g}$ copper sulfate, and $0.12 \mathrm{~g}$ sodium molybdate per $1000 \mathrm{~L}$ water.

Seven days after inoculation, the severity of infection was scored on a scale from 0 to 4 : $0=$ no visible symptoms; $1=\langle 1 \mathrm{~cm}$ diameter soaked lesion on the plant stem; $2=>$ $1 \mathrm{~cm}$ diameter soaked lesion on the plant stem; $3=$ partially necrotic lesion on the stem, with partial wilting of the plant;
Figure 1. Mean temperature and relative humidity at 24, 48 and $72 \mathrm{~h}$ after inoculation of Didymella bryoniae in melon seedlings in humid chamber. Jaboticabal, São Paulo, 2016.
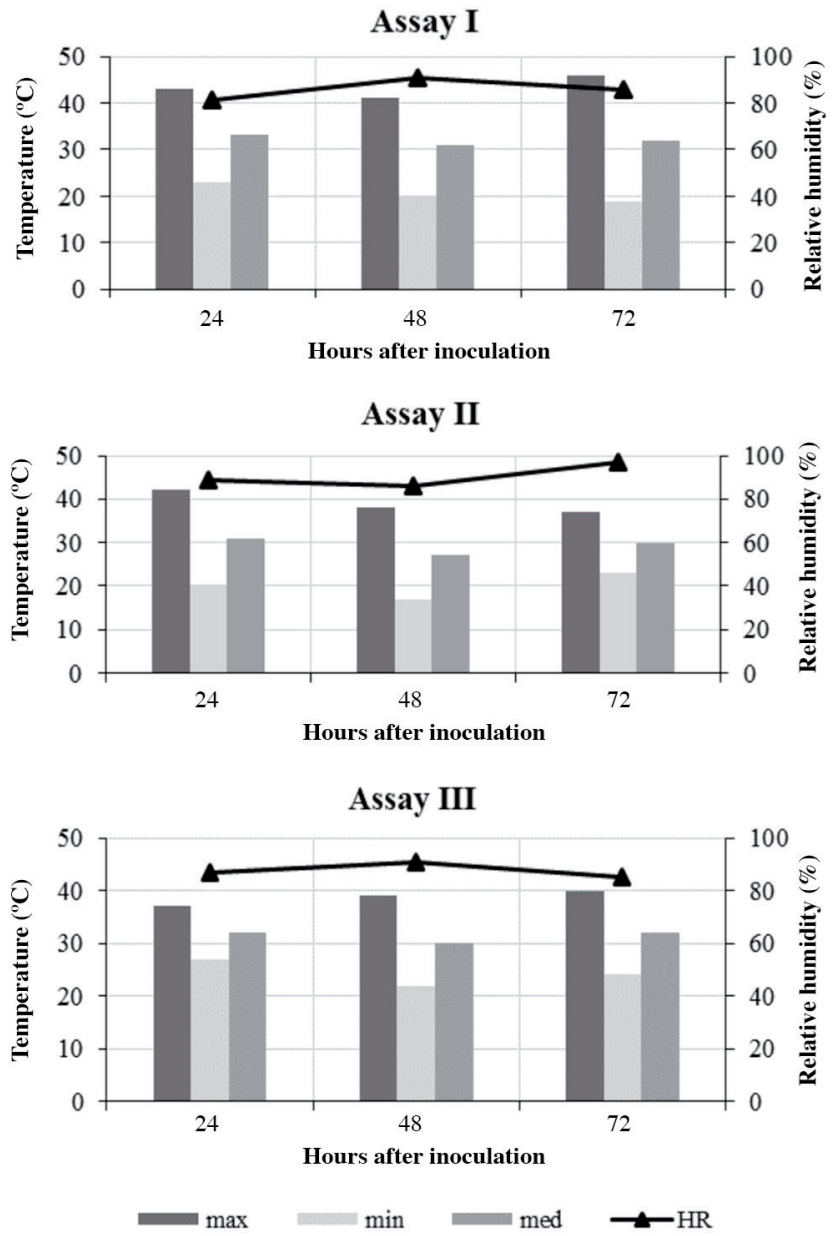

and $4=$ complete necrosis with total wilting and plant death.

The individual scores of each plant in each pot and the four replicates were used to obtain the average for each genotype. Based on the average severity scores, genotypes were classified into four reaction classes: $0.1-1.0=$ highly resistant $(\mathrm{HR}) ; 1.1-2.0=$ moderately resistant $(\mathrm{MR}) ; 2.1$ to $3.0=$ susceptible $(\mathrm{SU}) ; 3.1$ to $4.0=$ highly susceptible $(\mathrm{HS})$, adapted from Noronha et al. (2006).

\section{Validation of melon genotypes resistance to $D$. bryoniae - Assay 3}

Assay 3 was conducted to confirm resistance of genotypes that had lower scores for disease symptoms compared to previous assays between January and March 2014, using the methodology of resistance assessment in trays proposed by Santos et al. (2013).

We evaluated 14 genotypes: PI 420150, PI 532283, Charentais Fom 1, C160, AC-29; PI 482398, PI 140471, PI 420145 and PI 157082; JAB-11 and JAB-20 lines, commercial hybrids Louis $\mathrm{F}_{1}$ and Fantasy $\mathrm{F}_{1}$, and the genotype Flexuosos 'M-2791' included as susceptible control. 
Two seeds of each genotype were seeded per well in the 128-cell trays. Subsequently, plants were thinned, leaving only one seedling in each cell. The underground soil mix, tanned manure and commercial substrate Bioplant $(1: 2: 1)$ was used to fill the trays. The soil was previously sieved and sterilized by autoclaving at $120^{\circ} \mathrm{C}$ and $101.3 \mathrm{kPa}$, for $45 \mathrm{~min}$.

The experimental design was a randomized block design with three replicates and 14 treatments, using the genotypes mentioned above. Each plot consisted of eight seedlings in an eight-cell row in the tray. To avoid the microclimate, densification of seedlings and facilitate inoculation of seedlings, plots were interspersed by an empty-cell row in the tray.

When plants reached fully expanded second leaf stage, they were inoculated with the same strain, previously employed in assays 1 and 2, using the toothpick method (Verzignassi et al., 2004). Then, trays were placed in a humidity chamber and left for $72 \mathrm{~h}$. Subsequently, they were transferred to greenhouse for seedlings. Figure 1 shows mean temperature and relative humidity in the chamber during assay 3 .

The evaluation was performed $7 \mathrm{~d}$ after inoculation by assigning scores, as described and adopted in the previous assays. Subsequently, the scores were averaged and genotypes were classified according to the reaction classes adapted from Noronha et al. (2006).

\section{Statistical analysis}

To meet the basic assumptions of ANOVA (independence of errors, homogeneity of variance and normal distribution), average scores were root transformed $(x+1)$ and subjected to ANOVA. After this procedure, the average of each genotype was compared by Scott-Knott grouping test $(\mathrm{p}<$ 0.05) using the AgroEstat - System Analysis Agronomic Testing Statistics software, version 1.1.0.712, rev 77 (Barbosa and Maldonado Jr., 2015).

\section{RESULTS AND DISCUSSION}

\section{Reaction of melon genotypes to $D$. bryoniae}

The ANOVA results for the average score of symptoms to $D$. bryoniae showed significant difference between genotypes in assays 1 and 2. It was also observed that the overall severity average of disease symptoms and the coefficient of variation $(\mathrm{CV}, \%)$ had similar values in both assays, although separately conducted, for the transformed and nontransformed data (Tables 2 and 3 ).

The D. bryoniae isolate was pathogenic to melon seedlings since symptoms were already present in the first $24 \mathrm{~h}$ after inoculation. After $72 \mathrm{~h}$ of inoculation, it was possible to observe the typical symptoms of gummy stem blight with varying severity degrees, regarding lesion size, soggy appearance, gum oozing on the stem, and wilting to the point that plants tipped.

The controls did not show symptoms of the disease, nor other possible changes, showing that both the medium and
Table 2. Gummy stem blight severity in melon genotypes inoculated with Didymella bryoniae. Assay I. Jaboticabal, São Paulo, 2016.

\begin{tabular}{|c|c|c|c|}
\hline Genotype & Average & Reaction ${ }^{1}$ & Average transformed \\
\hline Flexuosus 'M-2791' & 3.31 & HS & $2.08 \mathrm{a}^{3}$ \\
\hline AC-11 & 2.81 & SU & $1.95 \mathrm{a}$ \\
\hline C246 & 2.62 & SU & $1.89 \mathrm{a}$ \\
\hline PI 414723 & 2.56 & SU & $1.87 \mathrm{a}$ \\
\hline $\mathrm{C} 68$ & 2.50 & SU & $1.85 \mathrm{a}$ \\
\hline C67 & 2.50 & SU & $1.86 \mathrm{a}$ \\
\hline JAB-11 & 2.88 & SU & $1.83 \mathrm{a}$ \\
\hline $\mathrm{C} 4$ & 2.31 & SU & $1.81 \mathrm{a}$ \\
\hline JAB-20 & 2.29 & SU & $1.81 \mathrm{a}$ \\
\hline PI 180280 & 2.25 & SU & $1.79 \mathrm{a}$ \\
\hline Solarking & 2.25 & SU & $1.80 \mathrm{a}$ \\
\hline $\mathrm{C} 70$ & 2.18 & SU & $1.78 \mathrm{a}$ \\
\hline PI 420149 & 2.06 & SU & $1.74 \mathrm{a}$ \\
\hline AC-30 & 2.06 & SU & $1.74 \mathrm{a}$ \\
\hline $\mathrm{C} 88$ & 2.00 & MR & $1.73 \mathrm{a}$ \\
\hline C 329 & 1.81 & MR & $1.66 \mathrm{a}$ \\
\hline AC-24 & 1.81 & MR & $1.67 \mathrm{a}$ \\
\hline PI 157082 & 1.75 & MR & $1.62 \mathrm{a}$ \\
\hline C384 & 1.69 & MR & $1.64 \mathrm{a}$ \\
\hline $\mathrm{C} 163$ & 1.62 & MR & $1.61 \mathrm{a}$ \\
\hline C265 & 1.56 & MR & $1.60 \mathrm{a}$ \\
\hline C190 & 1.44 & MR & $1.55 \mathrm{a}$ \\
\hline AC-17 & 1.34 & MR & $1.48 \mathrm{~b}$ \\
\hline C194 & 1.31 & MR & $1.52 \mathrm{~b}$ \\
\hline AC-23 & 1.31 & MR & $1.51 \mathrm{~b}$ \\
\hline C71 & 1.25 & MR & $1.50 \mathrm{~b}$ \\
\hline PI 482398 & 1.18 & MR & $1.48 \mathrm{~b}$ \\
\hline C189 & 1.12 & MR & $1.45 \mathrm{~b}$ \\
\hline PI 124111 & 1.06 & MR & $1.43 \mathrm{~b}$ \\
\hline C327 & 1.06 & MR & $1.42 \mathrm{~b}$ \\
\hline Kallósemjém & 0.94 & HR & $1.39 \mathrm{~b}$ \\
\hline AC-32 & 0.88 & HR & $1.35 \mathrm{~b}$ \\
\hline C359 & 0.81 & HR & $1.32 \mathrm{~b}$ \\
\hline AC-28 & 0.75 & HR & $1.30 \mathrm{~b}$ \\
\hline AC-24 & 0.62 & HR & $1.26 \mathrm{~b}$ \\
\hline PI 140471 & 0.19 & HR & $1.08 \mathrm{c}$ \\
\hline AC-29 & 0.19 & HR & $1.08 \mathrm{c}$ \\
\hline PI 420145 & 0.00 & HR & $1.00 \mathrm{c}$ \\
\hline PI 532830 & 0.00 & HR & $1.00 \mathrm{c}$ \\
\hline PI 420150 & 0.00 & HR & $1.00 \mathrm{c}$ \\
\hline $\mathrm{CV}, \%$ & 43.26 & & 12.85 \\
\hline General average & 1.45 & & 1.53 \\
\hline Test $\mathrm{F}$ & $6.32^{* *}$ & & $7.29^{* *}$ \\
\hline
\end{tabular}

${ }^{1}$ Reaction classes: $0.1-1.0=$ highly resistant $(\mathrm{HR}) ; 1.1-2.0=$ moderately resistant (MR); 2.1 to $3.0=$ susceptible $(\mathrm{SU}) ; 3.1$ to $4.0=$ highly susceptible (HS), adapted from Noronha et al. (2006).

${ }^{2}$ Average transformed into square root of $(x+1)$.

${ }^{3}$ Average followed by the same letter in the column do not differ significantly at $5 \%$ according to Scott-Knott test.

Significant at $1 \%$ by F Snedecor test.

the toothpick did not influence plant behavior regarding susceptibility to the pathogen.

According to reaction classes, of 40 genotypes evaluated in assay 1 (Table 2), 1 was highly susceptible, 13 susceptible, 16 moderately resistant, and 10 highly resistant. In the second experiment (Table 3), of 33 genotypes evaluated, 2 were highly susceptible, 10 susceptible, 9 intermediate resistant, and 12 highly resistant.

The Scott-Knott clustering test allowed grouping genotype means into three clusters, 22 susceptible, 13 moderately resistant and 5 highly resistant genotypes in assay 1 . Assay 2 formed four clusters, 5 highly susceptible, 11 susceptible, 13 moderately resistant, and 4 highly resistant. 
Table 3. Gummy stem blight severity in melon genotypes inoculated with Didymella bryoniae. Assay II. Jaboticabal, São Paulo, 2016.

\begin{tabular}{|c|c|c|c|}
\hline Genotype & Average & Reaction $^{1}$ & Average transformed ${ }^{2}$ \\
\hline Flexuosus 'M-2791' & 3.67 & HS & $2.16 \mathrm{a}^{3}$ \\
\hline Melão verdadeiro & 3.06 & HS & $2.01 \mathrm{a}$ \\
\hline PI 224786 & 2.92 & SU & $1.97 \mathrm{a}$ \\
\hline JAB-20 & 2.39 & SU & $1.96 \mathrm{a}$ \\
\hline Anô\#2 & 2.75 & SU & $1.92 \mathrm{a}$ \\
\hline Melão Eldorado 300 & 2.50 & SU & $1.85 \mathrm{~b}$ \\
\hline PI 124112 & 2.50 & SU & $1.85 \mathrm{~b}$ \\
\hline Cinco & 2.37 & SU & $1.83 \mathrm{~b}$ \\
\hline PMR-45 & 2.31 & SU & $1.81 \mathrm{~b}$ \\
\hline Perlita & 2.25 & SU & $1.80 \mathrm{~b}$ \\
\hline TM-001 & 2.15 & SU & $1.77 \mathrm{~b}$ \\
\hline JAB-11 & 2.15 & SU & $1.77 \mathrm{~b}$ \\
\hline AC-01 & 1.81 & MR & $1.67 \mathrm{~b}$ \\
\hline PI 179680 & 1.69 & MR & $1.64 \mathrm{~b}$ \\
\hline PI 313970 & 1.62 & MR & $1.61 \mathrm{~b}$ \\
\hline PI 157082 & 1.56 & MR & $1.60 \mathrm{~b}$ \\
\hline Melão Gaúcho & 1.44 & MR & $1.55 \mathrm{c}$ \\
\hline PI 179923 & 1.44 & MR & $1.55 \mathrm{c}$ \\
\hline C272 & 1.44 & MR & $1.53 \mathrm{c}$ \\
\hline PI 164320 & 1.31 & MR & $1.51 \mathrm{c}$ \\
\hline C72 & 1.31 & MR & $1.52 \mathrm{c}$ \\
\hline Mi-Tang-Ting & 0.94 & HR & $1.38 \mathrm{c}$ \\
\hline PI 140472 & 0.94 & HR & $1.36 \mathrm{c}$ \\
\hline AC-12 & 0.87 & HR & $1.35 \mathrm{c}$ \\
\hline PI 140471 & 0.81 & HR & $1.33 \mathrm{c}$ \\
\hline Irene & 0.81 & HR & $1.33 \mathrm{c}$ \\
\hline PI 224769 & 0.75 & HR & $1.31 \mathrm{c}$ \\
\hline AC-07 & 0.75 & HR & $1.30 \mathrm{c}$ \\
\hline Catucho & 0.62 & HR & $1.26 \mathrm{c}$ \\
\hline PI 482398 & 0.50 & HR & $1.22 \mathrm{~d}$ \\
\hline Charentais Fom 1 & 0.06 & HR & $1.03 \mathrm{~d}$ \\
\hline C160 & 0.06 & HR & $1.03 \mathrm{~d}$ \\
\hline PI 420145 & 0.00 & HR & $1.00 \mathrm{~d}$ \\
\hline $\mathrm{CV}, \%$ & 40.18 & & 12.71 \\
\hline General average & 1.58 & & 1.56 \\
\hline Test $\mathrm{F}$ & $9.38^{* * *}$ & & $9.74^{* *}$ \\
\hline
\end{tabular}

${ }^{1}$ Reaction classes: $0.1-1.0=$ highly resistant $(\mathrm{HR}) ; 1.1-2.0=$ moderately resistant (MR); 2.1 to $3.0=$ susceptible $(\mathrm{SU}) ; 3.1$ to $4.0=$ highly susceptible (HS), adapted from Noronha et al. (2006).

${ }^{2}$ Average transformed into square root of $(x+1)$;

${ }^{3}$ Average followed by the same letter in the column do not differ significantly at $5 \%$ according to Scott-Knott test.

Significant at $1 \%$ by $\mathrm{F}$ Snedecor test.

The genotype Flexuosus 'M-2791' was highly susceptible to $D$. bryoniae, regardless of the assays (Tables 2 and 3). The JAB-11 and JAB-20 lines were susceptible to D. bryoniae according to the reaction class in the two assays (Tables 2 and 3).

The cv. Eldorado 300 was classified as susceptible by the reaction class (Table 3); however, the Scott-Knott clustering test grouped it as highly susceptible and not significantly different from Flexuosus 'M-2791', Melão verdadeiro, PI 224786, and JAB-20. Tsutsumi and Silva (2004) evaluated the 'Eldorado 300' in plastic tunnel and greenhouse, and suggested it as susceptible control, which was also observed in this study.

'Mi-Tang-Ting' was highly resistant to $D$. bryoniae by the reaction classes, but the Scott-Knott cluster test grouped it as moderately resistant (Table 3 ). This genotype had intermediate resistance in crossings with susceptible genotypes, conditioned by two or three genes. 'Anô\#2', which is derived from 'Mi-Tang-Ting', was susceptible by both the reaction classes and Scott-Knott test (Table 3).

The PI's 140471, 157082, 420145 and 482398 have been classified as resistant in other studies, but assays 1 and 2 showed that PI 157082 had moderate resistance (Tables 2 and 3). PI 482398 also varied from moderately resistant in assay 1 to highly resistant in assay 2. The PI's 140471 and 420145 were highly resistant in both assays.

The most resistant genotypes according to reaction classes and the Scott-Knott test joint analyses were: PI 140471, AC-29, PI 420145, PI 532830 and PI 420150 (Table 2) in assay 1; and PI 482398, Charentais Fom 1, C160, PI 420145 (Table 3) in assay 2. It is noteworthy that PI 420145 had the lowest scores in both assays.

\section{Validation of melon genotype resistance to $D$. bryoniae}

Assay 3 was conducted to verify the stability of the results of assays 1 and 2 of genotypes that scored the lowest against the symptoms to gummy stem blight. Therefore, ANOVA and the Scott-Knott average clustering test were applied, to check the statistical difference between means at $5 \%$ probability (Table 4 ).

Table 4 shows that the overall assay average was higher compared to previous studies, indicating wider variation in the severity of disease symptoms. At $72 \mathrm{~h}$ after inoculation, most of the plants of assays 1 and 2 showed infection signs such as soaked stem aspect, thus indicating that all evaluated plants were infected with $D$. bryoniae isolate, differing only regarding the degree of infection severity (Table 4). The plants that were inoculated only with the medium in the sterile toothpick showed neither symptoms of the disease nor signs of infection at the injury.

Table 4. Behavior of melon genotypes inoculated with Didymella bryoniae in terms of disease severity, expressed as the level of resistance. Assay III, Jaboticabal, São Paulo, 2016.

\begin{tabular}{lccc}
\hline Genotype & Average & Reaction $^{1}$ & Average transformed \\
\hline Flexuosus 'M-2791' & 3.29 & $\mathrm{HS}$ & $2.07 \mathrm{a}^{3}$ \\
Louis F $_{1}$ & 2.79 & $\mathrm{SU}$ & $1.94 \mathrm{a}$ \\
Fantasy F $_{1}$ & 2.79 & $\mathrm{SU}$ & $1.94 \mathrm{a}$ \\
JAB-11 & 2.55 & $\mathrm{SU}$ & $1.88 \mathrm{a}$ \\
PI 420150 & 2.39 & $\mathrm{SU}$ & $1.84 \mathrm{a}$ \\
JAB-20 & 2.39 & $\mathrm{SU}$ & $1.84 \mathrm{a}$ \\
PI 157082 & 1.92 & $\mathrm{MR}$ & $1.68 \mathrm{a}$ \\
PI 140471 & 1.71 & $\mathrm{MR}$ & $1.64 \mathrm{a}$ \\
AC-29 & 0.63 & $\mathrm{HR}$ & $1.43 \mathrm{~b}$ \\
PI 5322830 & 0.92 & $\mathrm{HR}$ & $1.38 \mathrm{~b}$ \\
C160 & 0.71 & $\mathrm{HR}$ & $1.31 \mathrm{~b}$ \\
Charentais Fom 1 & 0.67 & $\mathrm{HR}$ & $1.29 \mathrm{~b}$ \\
PI 482398 & 0.50 & $\mathrm{HR}$ & $1.22 \mathrm{~b}$ \\
PI 420145 & 0.36 & $\mathrm{HR}$ & $1.16 \mathrm{~b}$ \\
CV, \% & 59.06 & & 18.79 \\
General average & 1.72 & & 1.60 \\
Test F & $3.06^{* *}$ & & $3.17^{* *}$ \\
\hline
\end{tabular}

${ }^{1}$ Reaction classes: $0.1-1.0=$ highly resistant $(\mathrm{HR}) ; 1.1-2.0=$ moderately resistant (MR); 2.1 to $3.0=$ susceptible (SU); 3.1 to $4.0=$ highly susceptible (HS), adapted from Noronha et al. (2006).

${ }^{2}$ Average transformed into square root of $(x+1)$

${ }^{3}$ Average followed by the same letter in the column do not differ significantly at 5\% according to the Scott-Knott test.

Significant at $1 \%$ by the F Snedecor test. 
According to the reaction class, 1 genotype was highly susceptible, 5 were susceptible, 2 were moderately resistant, and 6 were highly resistant. The Scott-Knott test, from the transformed average, clustered the genotypes into only two groups, 8 susceptible and 6 resistant (Table 4). It is noteworthy that the genotypes considered highly resistant coincided with the classification according to class reaction.

No genotype was found to be immune to the pathogen, since the genotypes PI 420145, PI 420150 and PI 532830 did not score zero. However, it was possible to distinguish different levels of resistance. Santos et al. (2013) studied watermelon and reported that none of the evaluated genotypes was immune to the pathogen, but the resistance levels were different.

Genotype Flexuosus 'M-2791' was stable. Based on this result, this genotype can be used as susceptibility control in studies to assess genotype resistance to D. bryoniae, as a susceptible control and to assess levels of pathogenicity of the isolates.

The JAB-11 and JAB-20 lines were susceptible to the pathogen (Table 4). Observed averages were similar to assays 1 and 2, whose susceptibility pattern was similar in all assays. The commercial hybrids, Louis $\mathrm{F}_{1}$ and Fantasy $\mathrm{F}_{1}$, were also susceptible to D. bryoniae and did not differ significantly from each other, at $5 \%$ probability by the Scott-Knott test (Table 4).

Genotype PI 420150 had a good level of resistance in assay 1 , but susceptible in assay 3 . This genotype may have suffered greater influence of environmental conditions in assay 3. Of the four PI's evaluated, PI 157082 was classified as moderately resistant. On the other hand, PI 140471, which was highly resistant in assays 1 and 2, was moderately resistant in assay 3 (Table 4).

Santos et al. (2009a), from the selection of a single plant pathogen isolate, evaluated the resistance of 86 melon genotypes to infection by $D$. bryoniae in a greenhouse. These authors reported that variation in resistance levels varied significantly between genotypes, and that five genotypes showed the lowest average lesion length (1.4 $\mathrm{cm})$. Comparing this information to the reaction classes used in this study, it should be noted that the plants with lesion length $>1.0 \mathrm{~cm}$ were ranked as intermediate resistant.

Wolukau et al. (2007) evaluated the resistance of PI's 420145, 140471 and 157082 and reported lesion length $\leq 1 \mathrm{~cm}$ for all genotypes, which were also considered resistant. However, in these studies, the authors inoculated the plants using suspensions of $\approx 5 \times 10^{5}$ conidia $\mathrm{mL}^{-1}$, and this method has been shown little effective to cause the emergence of symptoms. Due to the low applicability of this method, the direct insertion of toothpick with colony disk containing the fungus in the plant stem and close to the cotyledons has been recommended (Ito et al., 2009; Santos et al., 2009a; Silva et al., 2012).

The identification of new sources of resistance to $D$. bryoniae and the confirmation of the resistance of some PI's and cultivars observed in this work show good prospects for the management of this disease in melon, and can support breeding programs.
Regarding the definition of response patterns to gummy stem blight, most studies evaluating the resistance of melon genotypes to $D$. bryoniae use mean scores of lesion length to classify the response of these genotypes. Some use only the average scores and classify as resistant average score of 1 to 2 , and susceptible 3 to 4 . However, there are no reports of studies using a full-scale reaction. Therefore, the present study suggested a modified scale, which has been used in studies with other soil-borne pathogens, such as Myrothecium roridum (Noronha et al., 2006), Rhizoctonia solani (Michereff et al., 2008) and Macrophomina phaseolina (Ambrósio et al., 2015).

The analysis of genotype resistance by reaction class and Scott-Knott test shows that the average assay was strict in the formation of subgroup of highly resistant genotypes among those with high levels of resistance. Based on this result, the average assay was used to select the best within that group to evaluate resistance stability.

The fact that PI 157082 was moderately resistant in the three assays and PI 140471 moderately resistant in the third assay may be indicative of differences in the aggressiveness of the isolate used or environmental conditions. Some authors have reported the influence of environmental conditions and differences in the aggressiveness of isolates (Santos et al., 2009b; 2013).

The genotypes AC-29, PI 532830, C160, Charentais Fom 1, PI 482398, and PI 420145 were considered highly resistant, since they had the lowest scores on phenotyping assays and resistance confirmation assay, demonstrating greater resistance stability compared to other genotypes. Therefore, these genotypes are good choices as sources of resistance to $D$. bryoniae in melon.

The JAB-11 and JAB-20 lines were susceptible to $D$. bryoniae. Thus, it is necessary to introgress the resistance genes to obtain highly productive and resistant hybrids, since these exhibit high specific combining ability (Vargas et al., 2010). Thus, the resistance genes present in genotypes AC-29, PI 532830, C160, Charentais Fom 1, PI 482398 and PI 420145 can be used to develop varieties or hybrids with genes resistant to $D$. bryoniae from the strains JAB-11 and JAB-20 of the melon breeding program of UNESP-FCAV.

\section{CONCLUSION}

The melon genotypes AC-29, C160, Charentais Fom 1, PI 420145, PI 482398, and PI 532830 are resistant to Didymella bryoniae and can become an important alternative source of genes for the development of resistant cultivars.

\section{ACKNOWLEDGEMENTS}

The authors would like to thank the Coordenação de Aperfeiçoamento de Pessoal de Nível Superior - CAPES for the grant received and Universidade Estadual Paulista - UNESP/FCAV for the opportunity to pursue the doctor degree. 


\section{REFERENCES}

Agrianual. 2016. Anuário da agricultura brasileira. 485 p. FNP Consultoria e Comércio, São Paulo, Brasil.

Ambrósio, M.M.Q., Dantas, A.C.A., Martínes-Perez, E., Medeiros, A.C., Nunes, G.H.S., e Picó, M.B. 2015. Screening a variable germplasm collection of Cucumis melo $\mathrm{L}$. for seedling resistance to Macrophomina phaseolina. Euphytica 206:287300. doi:10.1007/s10681-015-1452-x.

Babu, B., Kefialew, Y.W., Li, P., Yang, X., George, S., Newberry, E., et al. 2015. Genetic characterization of Didymella bryoniae isolates infecting watermelon and other cucurbits in Florida and Georgia. Plant Disease 99:1488-1499. doi:10.1094/PDIS-04-140341-RE.

Barbosa, J.C., e Maldonado Jr., W. 2015. Experimentação agronômica e AgroEstat - Sistema para Análises Estatísticas de Ensaios Agronômicos. 396 p. FUNEP, Jaboticabal, Brasil.

Bi, Y.F., Xu, B., Qian, C., Guo, J., Zhang, Y., Yi, H., et al. 2015. Pyramiding disease resistance genes and variety improvement by molecular marker-assisted selection in melon (Cucumis melon L.) Scientia Agricultura Sinica 48:523-533. doi:10.3864/ j.issn.0578-1752.2015.03.12.

Gasparotto, F., Vida, J.B., Tessmann, D.J., e Alves, T.C.A. 2011. Infecção latente de Didymella bryoniae em meloeiro nobre. Summa Phytopathologica 37:62-64. doi:10.1590/S010054052011000100010.

Ito, L.A., Braz, L.T., Castoldi, R., Charlo, H.C.O., e Camargo, M. 2009. Seleção de portas enxertos resistentes ao Cancro-da-haste e seus efeitos na produtividade de melão 'Bônus 2'. Revista Brasileira de Fruticultura 31:262-267. doi:10.1590/S010029452009000100037.

Keinath, A.P. 2015. Baseline sensitivity of Didymella bryoniae to cyprodinil and fludioxonil and field efficacy of these fungicides against isolates resistant to pyraclostrobin and boscalid. Plant Disease 99:815-822 . doi:10.1094/PDIS-09-14-0993-RE.

Michereff, S.J., Andrade, D.E.G.T., e Sales Junior, R. 2008. Reaction of melon genotypes to Rhizoctonia solani. Horticultura Brasileira 26:401-404. doi:10.1590/S010205362008000300022.

Noronha, M.A., Michereff, S.J., Xavier Filha, M.S., Moreira, P.A.A., Reis, A., e Sales Jr., R. 2006. Reação de genótipos de meloeiro a Myrothecium roridum. Horticultura Brasileira 24:495-498. doi:10.1590/S0102-05362006000400020.
Santos, G.R., Castro Neto, M.D., Ramos, L.N., Café-Filho, A.C., Reis, A., Momenté, V.G., et al. 2009a. Reaction of melon genotypes to the gummy stem blight and the downy mildew. Horticultura Brasileira 27:160-165. doi:10.1590/S010205362009000200007.

Santos, G.R., Ferreira, M.A.S.V., Pessoa-Filho, M.A.C.P., Ferreira, M.E., and Café-Filho, A.C. 2009b. Host specificity and genetic diversity of Didymella bryoniae from Cucurbitaceae in Brazil. Journal of Phytopathology 157:265-273. doi:10.1111/j.14390434.2008.01475.x.

Santos, G.R., Leão, E.U., Garcia, M.M.V., Maluf, W.R., Cardon, C.H., Gonçalves, C.G., et al. 2013. Reação de genótipos experimentais de melancia ao crestamento gomoso do caule. Horticultura Brasileira 31:540-548. doi:10.1590/S010205362013000400006.

Silva, E.S., Palangana, F.C., Goto, R., Furtado, E.L., and Fernandes, D.M. 2012. Net melon resistance to Didymella bryoniae according to grafting and potassium levels. Summa Phytopathologica 38:139-143. doi:10.1590/S010054052012000200005.

Tsutsumi, C.Y., and da. Silva, N. 2004. Screening of melon populations for resistance to Didymella bryoniae in greenhouse and plastic tunnel conditions. Brazilian Archives of Biology and Technology 47:171-177. doi:10.1590/S151689132004000200002.

Vargas, P.F., Galatti, F.S., Souza, J.O., Castoldi, R., Charlo, H.C.O., e Braz, L.T. 2010. Avaliação de parentais e híbridos experimentais de melão rendilhado. Ciência e Agrotecnologia 34:1102-1108. doi:10.1590/S1413-70542010000500004.

Verzignassi, J.R., Vida, J.B., Gasparotto, F., Cortez, G.L.S., Lorenzetti, E.R., Faria, G.S.F., et al. 2004. Método do palito para inoculação de Didymella bryoniae em melão-nobre e pepino-“japonês”. Fitopatologia Brasileira 29:154 (Suplemento). Wolukau, J.N., Zhou, X., Li, Y., Zhang, Y., and Chen, J. 2007. Resistance to gummy stem blight in melon (Cucumis melo L.) germplasm and inheritance of resistance from plant introductions 157076, 420145, and 323498. HortScience 42:215-221. 